\title{
Multi-year evaluation of stocking rate and animal genotype on milk production per hectare within intensive pasture-based production systems
}

\author{
E. L. Coffey, ${ }^{*} \dagger^{1}$ L. Delaby, $\ddagger$ C. Fleming, ${ }^{*}$ K. M. Pierce, $\dagger$ and B. Horan ${ }^{*}$ \\ *Animal and Grassland Research and Innovation Centre, Teagasc Moorepark, Fermoy, Co. Cork, Ireland \\ †School of Agriculture, Food Science and Veterinary Medicine, University College Dublin, Belfield, Dublin 4, Ireland \\ łINRA, AgroCampus Ouest, UMR 1348, Physiologie, Environnement et Génétique pour l'Animal et les Systèmes d'Elevage, F-35590 Saint-Gilles, \\ France
}

\section{ABSTRACT}

The objective of this experiment was to evaluate the effect of stocking rate (SR) and animal genotype (BR) on milk production, body weight (BW), and body condition score (BCS) within intensive pasture-based systems. A total of 533 lactation records, from 246 elite genetic merit dairy cows were available for analysis; 68 Holstein-Friesian $(\mathrm{HF})$ and 71 Jersey $\times$ HolsteinFriesian (JxHF) crossbred cows in each of 4 consecutive years (2013-2016, inclusive). Cows from each BR were randomly allocated to 1 of 3 whole-farm comparative SR treatments, low (LSR; 1,200 kg of BW/ha), medium (MSR; 1,400 kg of BW/ha), and high (HSR; 1,600 kg of $\mathrm{BW} / \mathrm{ha}$ ), and remained in the same $\mathrm{SR}$ treatments for the duration of the experiment. The effects of SR, $\mathrm{BR}$, and their interaction on milk production/cow and per hectare, BW, BCS, and grazing characteristics were analyzed. Total pasture utilization per hectare consumed in the form of grazed pasture increased linearly as SR increased: least in LSR (10,237 kg of dry matter/ ha), intermediate in MSR (11,016 kg of dry matter/ha), and greatest in HSR (11,809 kg of dry matter/ha). Milk and milk solids (MS) yield per hectare was greatest for HSR (15,942 and 1,354 kg, respectively), intermediate for MSR (14,191 and 1,220 kg, respectively), and least for LSR (13,186 and 1,139 kg, respectively) with similar trends evident for fat, protein, and lactose yield/ ha. At higher SR (MSR and HSR), MS yield per $\mathrm{kg}$ of BW per ha was reduced (0.85 and $0.82 \mathrm{~kg}$ of MS/ $\mathrm{kg}$ of BW, respectively) compared with LSR (0.93 kg of $\mathrm{MS} / \mathrm{kg}$ of $\mathrm{BW} / \mathrm{ha})$. Holstein-Friesian cows achieved fewer grazing days per hectare $(-37 \mathrm{~d})$, and produced more milk $(+561 \mathrm{~kg} / \mathrm{ha})$ but less fat plus protein $(-57$ $\mathrm{kg} / \mathrm{ha}$ ) compared with JxHF cows; the JxHF cows

Received August 4, 2017.

Accepted October 27, 2017.

${ }^{1}$ Corresponding author: emmalouise.coffey@teagasc.ie were lighter. At similar BW per hectare, JxHF cows produced more fat plus protein/ha during the grazing season at low (1,164 vs. $1,113 \mathrm{~kg})$, medium (1,254 vs. $1,185 \mathrm{~kg})$, and high (1,327 vs. $1,380 \mathrm{~kg})$ SR. In addition, JxHF cows produced more fat plus protein per $\mathrm{kg}$ of BW/ha (0.90 kg) compared with HF cows $(0.84 \mathrm{~kg})$. The results highlight the superior productive efficiency of high genetic potential crossbred dairy cows within intensive pasture-based production systems.

Key words: stocking rate, crossbreeding, milk production, pasture-based

\section{INTRODUCTION}

Population growth, urbanization, and increasing disposable income are contributing to an increase in the demand for dairy products globally (Delgado, 2003; Robinson et al., 2015). This poses a challenge for agricultural production to use the available feed resources more efficiently, without adverse consequences for the natural environment. Consequently, the term sustainable intensification has been defined as the challenge of producing more food from the same resources, while reducing environmental effects of agricultural production (Pretty, 1997). In the context of pasture-based production systems, land is the limiting resource to productivity, and therefore, optimizing output per hectare through increasing pasture accumulation and utilization is pertinent to the sustainable intensification of grazing systems of animal production.

Stocking rate (SR), traditionally defined as the number of cows per unit area of land used during a defined period (i.e., cows/ha), is widely recognized as the primary lever to systematically improve pasture accumulation and utilization, and milk production per hectare while simultaneously reducing the requirement for external supplementary feed imports in grazing systems (Hoden et al., 1991; Macdonald et al., 2008a,b; McCarthy et al., 2016). Previous studies have also reported that cows/ha is a misleading measure of SR (Holmes et al., 2002), as it fails to account for variable 
pastureland productivity, nonpasture supplementation levels, and the diverse requirements of different dairy cow types commonly used within such systems. Consequently, McCarthy et al. (2011) expressed the effects of increasing SR on cow performance $/ 100 \mathrm{~kg}$ of additional BW per ha as a more appropriate alternative measure of the SR effect within a predominantly pasture-fed dairy system. As SR increases, milk production per hectare increases linearly, whereas milk production per cow declines (McMeekan and Walshe, 1963; Macdonald et al., 2008a; McCarthy et al., 2011). In grazing terms, increasing SR increases grazing intensity and pasture utilization, resulting in higher pasture productivity and improved sward quality (Macdonald et al., 2008a; McCarthy et al., 2016).

Intensive grazing systems require a robust easy-care cow that has the capacity to efficiently convert pasture to high value fat plus protein [milk solids (MS); Berry, 2015]. Although Holstein-Friesian (HF) is the predominant breed within the Irish national dairy herd (Department of Agriculture, Food and the Marine, 2015), the inclusion of functional traits in the Irish total merit breeding index [Economic Breeding Index (EBI); ICBF, 2014], the introduction of a multi-component milk payment system rewarding fat and protein production and penalizing milk volume (Shalloo et al., 2007), and expanding herd sizes at farm level have contributed to an increasing interest in crossbreeding at farm level. The suitability of Jersey $\times$ Holstein-Friesian $(\mathbf{J x H F})$ crossbred cows to intensive grazing systems is widely acknowledged in the literature by virtue of their small size and comparatively large intake potential (Mackle et al., 1996; Prendiville et al., 2009; Vance et al., 2013), JxHF cattle represent the near ideal cow for grazing systems and have displayed superior MS production and feed conversion efficiency compared with traditional HF counterparts in recent studies (Prendiville et al., 2009; Beecher et al., 2014; Coffey et al., 2017).

Although the results of these animal genotype (BR) comparison experiments are unequivocal, it is also widely acknowledged that comparing animals of differing BW (and associated maintenance requirements) on an individual animal basis confers a systemic advantage to the smaller animal (McCarthy et al., 2013; Dong et al., 2015). Notwithstanding the frequency of international BR comparison studies, it remains unclear if the superiorities reported for JxHF cows are consistently achieved across a wide array of intensive grazing management systems where SR may be more accurately defined in terms of BW per hectare and where feed inputs are consistently regulated. Consequently, the objective of the present experiment was to evaluate the interaction of SR and BR on milk production per hectare and associated effects of grazing characteristics, BW, and BCS within pasture-based milk production systems wherein SR is defined in terms of kilograms of BW per hectare and using high genetic merit spring-calving dairy cows of both BR groups combined with intensive grazing management practices over a 4 -yr period.

\section{MATERIALS AND METHODS}

The experiment was undertaken at the Animal \& Grassland Research and Innovation Center, Teagasc Moorepark, Ireland $\left(50^{\circ} 7 \mathrm{~N}, 8^{\circ} 16 \mathrm{~W}\right)$, over a 4 -yr period (2013-2016, inclusive). A total of 533 lactations from 246 spring-calving dairy cows were analyzed, with 139 cows used in each year of the experiment. It formed part of a larger experiment designed to examine the biological and economic effects of alternative SR and BR combinations. A more detailed description of the cows, treatments, and experimental design has been previously reported (Coffey et al., 2017).

\section{Experimental Design, Treatments, and Cows}

The experiment was a randomized block design with a $3 \times 2$ factorial arrangement of treatments. In each year, the 6 experimental treatments consisted of 3 whole-farm SR $(1,200,1,400$, and $1,600 \mathrm{~kg}$ of BW/ ha) and 2 BR (HF and JxHF). The SR (cows/ha) corresponded to 2.4, 2.9, and 3.3 cows/ha for LSR, MSR, and HSR for HF cows, respectively, and 2.5, 3.0, and 3.4 cows/ha for LSR, MSR, and HSR for JxHF cows, respectively. The average EBI, milk, fertility, calving, beef, maintenance, management, and health sub-indices of the HF cows were $€ 205,63,103,33,-12,15,2$, and -1 , respectively, and $€ 198,68,89,30,-24,32,3$, and -1 , respectively, for the JxHF cows. The average EBI of the cows of both BR during the experiment (ICBF, 2015) ranked them in the top $1 \%$ of the national herd during the same period.

Cows within each BR were randomly assigned precalving based on expected calving date, parity, and EBI to 1 of 3 SR treatments: low (LSR; $1,200 \mathrm{~kg}$ of $\mathrm{BW} / \mathrm{ha}$ ), medium (MSR; 1,400 $\mathrm{kg}$ of $\mathrm{BW} / \mathrm{ha}$ ), and high (HSR; $1,600 \mathrm{~kg}$ of BW/ha). The LSR treatment was designed to allow individual cows to achieve a high level of pasture allowance and milk production per cow, whereas the MSR and HSR treatments were designed to investigate the potential to increase pasture utilization and milk production per hectare through increasing SR and grazing intensity while reducing feed allowance per cow. The SR implemented in the MSR and HSR treatments were 17 and $33 \%$ greater, respectively, than the LSR treatment. 


\section{Grazing Management and Feed System}

A total of 48.1 ha of permanent grassland, predominantly perennial ryegrass (Lolium perenne), was used for the duration of the experiment. All swards were reseeded during the previous $10 \mathrm{yr}$. Each of the 6 treatments had a separate farmlet of 18 paddocks, with each farmlet balanced for location block, sward species, and soil type. Each farmlet remained in the same SR treatment for the duration of the experiment. Total farmlet area for LSR, MSR, and HSR was 9.17, 7.87, and 7.01 ha, respectively, for each BR. Mineral N fertilizer application was $250 \mathrm{~kg}$ of $\mathrm{N} /$ ha per $\mathrm{yr}$ for each SR treatment.

Cows were turned out to pasture by day and night, as they calved, from early February. A rotational-stocking system was practiced, and on-off grazing (Kennedy et al., 2009) was used as a management tool to facilitate grazing during periods of inclement weather. Grazing management was accomplished by weekly monitoring of farm pasture cover within each SR treatment. Animal genotype within each SR was grazed in sub-paddocks adjacent to each other and was managed similarly [i.e., similar target pregrazing pasture mass (prePM), postgrazing surface height (postGSH), and residency time in paddocks]. Target postGSH were 45 to 50, 40 to 45 , and 35 to $40 \mathrm{~mm}$ for LSR, MSR, and HSR, respectively, and groups were moved to the next paddock once target postGSH was reached. Weekly grazing management during the first rotation (February 1 to April 1) was based on allocating an equal and increasing proportion of each farmlet area to each treatment until the start of rotation 2. During the main grazing season (April to August), the target rotation length was $21 \mathrm{~d}$. Target prePM was different for each SR and was calculated using the following equation:

$$
\begin{aligned}
& \text { target prePM }(\mathrm{kg} \text { of } \mathrm{DM} / \mathrm{ha})=[\mathrm{SR}(\text { cows } / \text { ha }) \\
& \times \text { rotation length } \times \mathrm{DPA} / \mathrm{cow}] \\
& + \text { residual pasture mass }
\end{aligned}
$$

where DPA = daily pasture allowance. When prePM in the next paddock exceeded target prePM, the paddock was not grazed and instead was harvested as silage to maintain sward quality for grazing. All silage was conserved in bales and weighed approximately $260 \mathrm{~kg}$ of $\mathrm{DM} /$ bale. A sample of pasture was taken before baling for DM determination. No mechanical topping of the swards took place for the duration of the experiment.

The aim was to feed equal amounts of concentrate per hectare regardless of SR, and therefore, increasing SR did not result in increased concentrate supplemen- tation per cow. Concentrate supplementation was approximately $1,000 \mathrm{~kg}$ of $\mathrm{DM} / \mathrm{ha}(400,345$, and $305 \mathrm{~kg}$ of DM/cow for LSR, MSR, and HSR, respectively). At higher SR, additional feed requirements were provided through increased pasture accumulation and utilization or the provision of bale silage and concentrates during periods of inadequate pasture supply. Concentrate supplementation for all treatments commenced at 4 $\mathrm{kg} / \mathrm{d}$ postcalving and was reduced and removed only when pasture supply exceeded animal demand (usually in mid-March). Concentrate was reintroduced when pasture supply was inadequate. When a feed deficit arose for one of the 3 SR treatments, conserved forage produced within that SR treatment was used to supplement pasture supply. The ingredient composition of the concentrate feed was barley $25 \%$, corn gluten $26 \%$, beet pulp $35 \%$, soybean meal $11 \%$, and minerals plus vitamins $3 \%$. Mean concentrate quality was $154 \mathrm{~g} /$ $\mathrm{kg}$ of $\mathrm{CP}, 177 \mathrm{~g} / \mathrm{kg}$ of crude fiber, $105 \mathrm{~g} / \mathrm{kg}$ of ash, and $895 \mathrm{~g} / \mathrm{kg}$ of OM.

\section{Pasture Measurements}

Grazing data were collected from all paddocks grazed during each grazing rotation in each year of the experiment. Pregrazing PM was determined before grazing in all paddocks for each of the 6 farmlets by harvesting a strip $(1.2 \times 10 \mathrm{~m})$ of pasture with an Etesia mower to a height of $35 \mathrm{~mm}$ (Etesia UK Ltd., Warwick, UK). All mown pasture from each strip was collected and weighed, and a $0.1-\mathrm{kg}$ (fresh weight) subsample was taken and dried for $16 \mathrm{~h}$ at $90^{\circ} \mathrm{C}$ for $\mathrm{DM}$ determination. Ten surface height $(\mathbf{S H})$ measurements were recorded before and after harvesting on each cut strip using a folding plate meter with a steel plate (Jenquip, Fielding, New Zealand). Sward density was calculated, using the measurement below (Delaby and Peyraud, 1998):

sward density $(\mathrm{kg}$ of $\mathrm{DM} / \mathrm{mm}$ per ha $)=$ pasture mass

(kg of DM/ha)/(pre-cutting SH - postcutting SH).

Pre- and postgrazing SH were determined for each paddock before and after grazing by taking $30 \mathrm{SH}$ measurements across the diagonal of the paddock. The average paddock prePM and DPA above a cutting height of 35 $\mathrm{mm}$ was then calculated using the measurements below,

$$
\begin{gathered}
\text { PrePM }(\mathrm{kg} \text { of DM/ha })=[\text { pre-grazing } \mathrm{SH}(\mathrm{mm}) \\
-35 \mathrm{~mm}] \times \text { sward density }(\mathrm{kg} \text { of } \mathrm{DM} / \mathrm{mm} \text { per ha }) .
\end{gathered}
$$

Pasture disappearance was calculated using the formula: 
pasture disappearance $=($ preSH - postSH $)$

$$
\times \text { sward density. }
$$

Daily pasture allowance and daily pasture disappearance were calculated based on residency time within each paddock. Estimated total feed intake (kg of DM/ cow per d) was calculated by adding daily pasture disappearance and supplementation (daily concentrate and silage). Grazing data were analyzed across 3 periods of the grazing season: spring (turnout to March 31), summer (April 1 to July 31), and autumn (August 1 to housing). Spring and autumn corresponded to early and late lactation, respectively, where pasture growth was restricted and demand exceeded supply, and summer corresponded to mid lactation where pasture supply exceeded demand.

\section{Chemical Analysis}

A sub-sample of pasture was collected from each paddock when pasture was harvested with the Etesia mower for each SR treatments across 5 time points each year. The 5 time points included the first rotation (February 1 to April 1), three 21-d rotations during the main grazing season, and the final rotation (October 1 to November 20). Pasture samples were freeze-dried at $-60^{\circ} \mathrm{C}$ for $48 \mathrm{~h}$ and milled through a 1-mm sieve. Samples were analyzed for DM, ash, ADF, NDF (Van Soest, 1963), CP (Leco FP-428, Leco Australia Pty Ltd., Baulkham Hills, New South Wales, Australia), and organic matter digestibility (OMD) (Morgan et al., 1989). The energy content of the pasture was calculated for each SR based on the net energy system (Faverdin et al., 2011), where 1 unité fourragère lait (UFL) of energy was defined as the net energy content of $1 \mathrm{~kg}$ of standard barley for milk production, equivalent to $1,700 \mathrm{kcal}$.

\section{Animal Measurements}

Cows were milked twice daily throughout lactation across the $4 \mathrm{yr}$ of the experiment. The milking process was carried out at 0700 and $1530 \mathrm{~h}$ daily. Weekly milk production was derived from individual cow milk yield $(\mathrm{kg})$ recorded at each milking (Dairymaster, Causeway, Co. Kerry, Ireland). Milk fat, protein, and lactose concentrations for each cow were determined from successive p.m. and a.m. milkings using a Milkoscan 203 (Foss Electric DK-3400, Hillerod, Denmark), and subsequently, weekly solids-corrected milk (SCM; Tyrrell and Reid, 1965), fat, protein, lactose, and MS yields were calculated. Milk, SCM, fat, protein, lactose, and MS yield per hectare (from grazed pasture) were calculated by measuring the total milk produced from each paddock in each treatment and dividing by the area of the paddock to give the yield per hectare. Similarly, grazing days per hectare was calculated by dividing the total number of grazing days in each paddock for each treatment by the area of the paddock. Individual cow BW and BCS were recorded fortnightly. Body weight was recorded upon exit from the milking parlor using an electronic scale (Tru-Test Limited, Auckland, New Zealand). Cow BCS was measured on a 1 to 5 scale $(1=$ thin, $5=$ fat $)$ in increments of 0.25 as outlined by Edmonson et al. (1989). Body condition score was recorded by one individual throughout the experiment. Milk production efficiency per hectare was calculated based on the net energy system of Faverdin et al. (2011). The measure of milk production efficiency considered in the present experiment was MS (g/ha) produced relative to total feed intake, accounting for energy requirements and feed utilization per hectare.

\section{Statistical Analysis}

All statistical analysis was carried out using SAS (SAS Institute Inc., 2010). The effect of year, SR, $\mathrm{BR}$, and season on net pasture accumulation, chemical composition of pasture, prePM, pre- and postGSH, DPA, daily pasture disappearance, pasture utilization, and concentrate and forage supplementation were analyzed using mixed models (PROC MIXED). Year (2013-2016, inclusive), SR (low, medium, high), BR (HF and JxHF), and season (spring, summer, autumn) were included as fixed effects in the model. The effect of year, parity, SR, BR, season, calving date, genetic merit, and their interactions on milk, SCM, fat, protein, lactose, and MS yield/cow were analyzed using mixed models (PROC MIXED). Year (2013-2016, inclusive), parity (1, 2, $\geq 3$ ), SR (low, medium, high), BR (HF and JxHF), and season (spring, summer, autumn) were included as fixed effects, whereas calving day of year and genetic merit (EBI) were included as continuous effects. To take account of multiple measurements for individual cows, cow year was included as a random effect in the model. The effect of year, SR, BR, SR $\times$ $\mathrm{BR}$, number of grazings, and paddock-block on milk per hectare, SCM per hectare, fat per hectare, protein per hectare, lactose pre hectare, MS per hectare, and $\mathrm{MS} / \mathrm{kg}$ of BW per hectare from grazed pasture and the number of grazing days per hectare were analyzed using mixed models (PROC MIXED). Year (2013-2016, inclusive), SR (low, medium, high), and BR (HF and $\mathrm{JxHF}$ ) were included as fixed effects and the number of grazings $(2-10)$ was included as a continuous effect. To take account of multiple measurements for individual paddocks, paddock-block was included as a random effect in the model. Differences between experimental 
treatment groups were deemed to be statistically significant where $P<0.05$. $P<0.05$ was considered significant, and $P<0.01$ and $P<0.001$ were considered highly significant.

\section{RESULTS}

\section{Climate Data}

Total monthly rainfall and mean daily temperature for each year of the experiment and the 20-yr mean are presented in Table 1. Total rainfall averaged 1,094 $\mathrm{mm}$ during the $4 \mathrm{yr}$ compared with $1,051 \mathrm{~mm}$ during the 1996 to 2015 period. Total rainfall was below the 20-yr average in 2013 and 2016 (-105 and -72 $\mathrm{mm}$, respectively) and above average in 2014 and 2015 $(+189$ and $+159 \mathrm{~mm}$, respectively). Compared with the 20-yr average (449 mm), mid-season (April to September, inclusive) rainfall was low in 2013 and 2014 (321 and $387 \mathrm{~mm}$, respectively) and similar to the long-term average in both 2015 and 2016 (457 and $461 \mathrm{~mm}$, respectively). Mean daily temperatures during the $4 \mathrm{yr}$ of the experiment $\left(10.0^{\circ} \mathrm{C}\right)$ were similar to the $20-\mathrm{yr}$ average $\left(10.1^{\circ} \mathrm{C}\right)$.

\section{Pasture Accumulation, Grazing Characteristics, and Dietary Details}

The effect of SR on net pasture accumulation is presented in Table 2. The effect of SR on pasture accumulation approached significance $(P=0.15)$, due to increased total net pasture accumulation in HSR $(15,386 \mathrm{~kg}$ of DM/ha) relative to both LSR and MSR (14,782 and 14,785 $\mathrm{kg}$ of DM/ha, respectively) during the 4-yr experimental period. Net pasture accumulation between paddocks ranged from a minimum of $12,144 \mathrm{~kg}$ of DM/ha to a maximum of $18,177 \mathrm{~kg}$ of $\mathrm{DM} /$ ha per yr and between yr from 13,482 $\mathrm{kg}$ of $\mathrm{DM} / \mathrm{ha}$ in 2013 to $16,242 \mathrm{~kg}$ of $\mathrm{DM} / \mathrm{ha}$ in 2016 . A similar number of grazings were achieved/paddock in all SR treatments (6.7 grazings/paddock), whereas each paddock was cut for silage within the LSR (1.0 cuts/paddock) compared with only $80 \%$ of the area in the MSR and HSR. There was also no significant difference between SR treatments in terms of rotation length during the year. Although turnout date was similar for each SR (d 32 of yr; February 2), the grazing season of the LSR treatment (d 320 of yr; November 17) was prolonged $(P=$ 0.01 ) during autumn compared with MSR (November 13) and HSR (November 12).

The effect of SR, BR, and their interaction on grazing characteristics is presented in Table 3. Pre-grazing $\mathrm{PM}$ and $\mathrm{SH}$ was similar for MSR (1,652 $\mathrm{kg}$ of DM/ha and $87 \mathrm{~mm}$, respectively) and HSR (1,675 kg of DM/

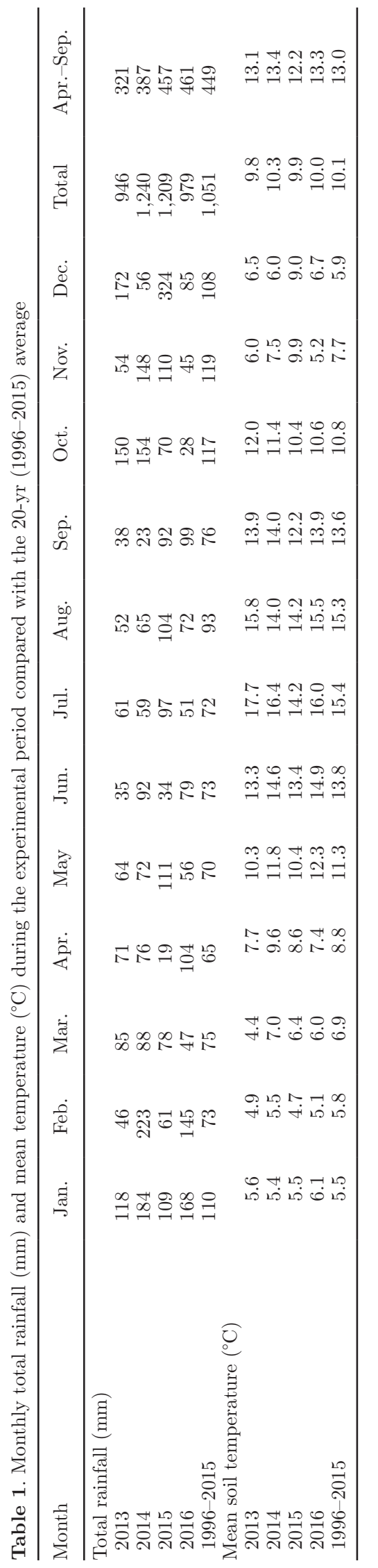


Table 2. Effect of stocking rate $^{1}$ on cumulative pasture accumulation and grazing characteristics during the experiment

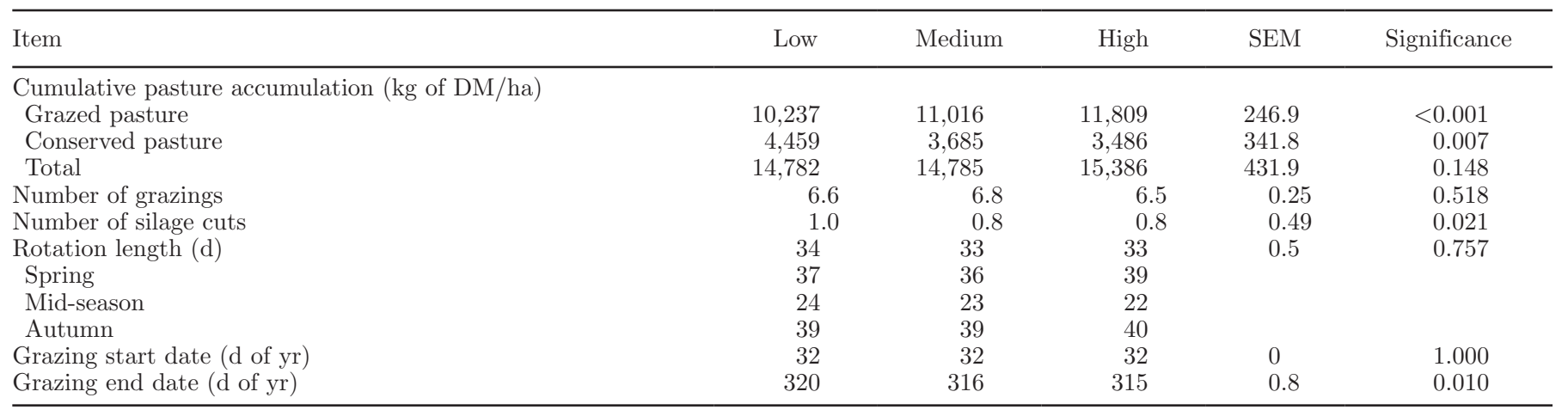

${ }^{1}$ Stocking rate: low $=1,200 \mathrm{~kg}$ of $\mathrm{BW} / \mathrm{ha}$; medium $=1,400 \mathrm{~kg}$ of $\mathrm{BW} / \mathrm{ha}$; high $=1,600 \mathrm{~kg}$ of $\mathrm{BW} / \mathrm{ha}$.

ha and $87 \mathrm{~mm}$, respectively), and greatest $(P<0.001)$ for LSR (1,759 kg of DM/ha and $88 \mathrm{~mm}$, respectively). Postgrazing PM and $\mathrm{SH}$ was greatest $(P<0.001)$ for LSR (314 $\mathrm{kg}$ of DM/ha and $45 \mathrm{~mm}$, respectively), intermediate for MSR (109 kg of DM/ha and $39 \mathrm{~mm}$, respectively), and least for $\mathrm{HSR}$ (9 $\mathrm{kg}$ of $\mathrm{DM} / \mathrm{ha}$ and $35 \mathrm{~mm}$, respectively). Daily pasture allowance, pasture disappearance, and pasture utilization during the experiment are presented in Table 4. Average DPA/cow was greatest $(P<0.001)$ for LSR $(19.0 \mathrm{~kg}$ of DM), intermediate for MSR (15.1 kg of DM), and least for HSR (14.0 kg of DM). Average daily pasture disappearance/ cow was also greatest $(P<0.001)$ for LSR $(15.5 \mathrm{~kg}$ of $\mathrm{DM})$ and similar for both MSR and HSR (13.9 kg of DM). Consequently, pasture utilization was greatest $(P$ $<0.001$ ) for HSR (100\%), intermediate for MSR (94\%), and least for LSR (83\%). Average DPA and pasture disappearance were greater $(P<0.001)$ for HF cows (16.3 and $14.7 \mathrm{~kg}$ of DM, respectively) than JxHF cows (15.7 and $14.2 \mathrm{~kg}$ of DM, respectively). Daily pasture allowance and pasture disappearance were greatest $(P$ $<0.001$ ) in summer (16.9 and $15.1 \mathrm{~kg}$ of DM, respectively), intermediate in autumn (15.5 and $14.1 \mathrm{~kg}$ of DM, respectively), and least in spring (9.8 and $10.1 \mathrm{~kg}$ of DM, respectively). Within each SR, DPA and pasture disappearance was lower for JxHF cows, although pasture utilization was unaffected by BR.

Concentrate supplementation/cow per lactation was greater $(P<0.01)$ for LSR $(462 \mathrm{~kg}$ of $\mathrm{DM})$ compared with MSR (430 kg of DM) and HSR (426 kg of DM). Silage supplementation/cow per lactation was least $(P<0.001)$ for LSR $(69 \mathrm{~kg}$ of $\mathrm{DM})$, intermediate for MSR (148 kg of DM), and greatest for HSR (183 kg of DM). Supplementation per hectare during the grazing season increased as SR increased. Annual concentrate and silage supplementation per hectare was greatest $(P<0.001)$ for HSR $(1,446$ and $609 \mathrm{~kg}$ of DM, respectively), intermediate for MSR (1,307 and $444 \mathrm{~kg}$ of DM, respectively), and least for LSR (1,150 and $170 \mathrm{~kg}$ of DM, respectively).

\section{Sward Nutritive Quality}

Stocking rate did not have a significant effect on sward chemical composition during the grazing season (Table 5). Average CP, OMD, NDF, ADF, and UFL were 211 $\mathrm{g} / \mathrm{kg}, 78 \%, 448,258 \mathrm{~g} / \mathrm{kg}$, and $0.96 \mathrm{UFL}$, respectively, across the grazing season. Crude protein was similar in spring $(225 \mathrm{~g} / \mathrm{kg})$ and autumn $(229 \mathrm{~g} / \mathrm{kg})$, and least $(P<0.001)$ in summer $(202 \mathrm{~g} / \mathrm{kg})$. Organic matter digestibility was similar for spring and summer (80\%), and least in autumn (77\%). Neutral detergent fiber and ADF were lowest $(P<0.001)$ during spring $(429$ and $247 \mathrm{~g} / \mathrm{kg}$, respectively), intermediate during summer (437 and $259 \mathrm{~g} / \mathrm{kg}$, respectively), and greatest during autumn (452 and $265 \mathrm{~g} / \mathrm{kg}$, respectively). The decline in OMD and the increase in NDF and ADF from spring and summer to autumn resulted in a decline in UFL (1.0 UFL in spring to 0.94 UFL in autumn).

\section{Milk Production per Cow}

The effect of SR, BR, and their interaction on individual cow milk production is presented in Table 6 . Both SR and BR had significant effects on milk production characteristics, whereas no significant interaction between SR and BR was observed. As SR increased, a linear decline was observed in lactation length and milk production per cow (milk, SCM, fat, protein, lactose, and MS yield). The greatest $(P<0.001)$ total milk, SCM, and MS yield was observed in LSR $(5,282$, 5,390 , and $456 \mathrm{~kg}$, respectively), whereas HSR was least $(4,863,4,866$, and $414 \mathrm{~kg}$, respectively) and MSR was intermediate $(5,032,5,074$, and $432 \mathrm{~kg}$, respectively). Similarly, protein and lactose composition was greatest $(P<0.001)$ for LSR, least for HSR, and intermediate 
COFFEY ET AL.
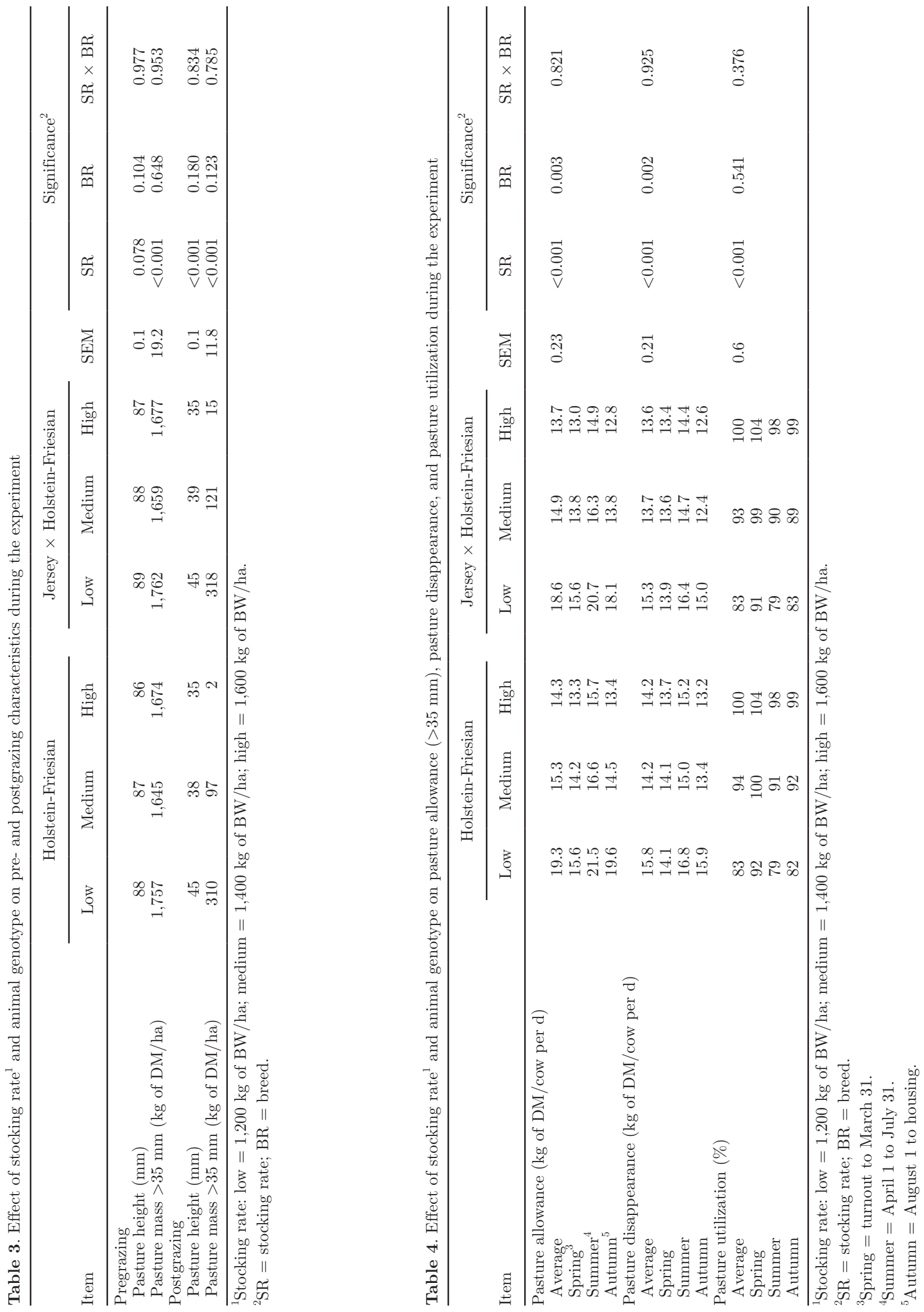
for MSR. Fat composition was similar for LSR (48.7 $\mathrm{g} / \mathrm{kg})$ and HSR $(49.1 \mathrm{~g} / \mathrm{kg})$, and greater $(P=0.05)$ in MSR $(49.8 \mathrm{~g} / \mathrm{kg})$. Genotype also had a significant effect on milk, fat, lactose, and MS yield. Holstein-Friesian cows produced greater milk $(+318 \mathrm{~kg} ; P<0.001)$ and lactose $(+12 \mathrm{~kg} ; P<0.001)$ yields compared with JxHF cows. Notwithstanding this, JxHF cows produced more fat $(+12 \mathrm{~kg} ; P<0.001)$ and MS $(+10 \mathrm{~kg} ; P=0.02)$ compared with HF cows. Similarly, fat, protein, and lactose composition was greater $(P<0.001)$ for JxHF cows $(+0.42,+0.15$, and $+0.04 \%$, respectively).

\section{$B W$ and $B C S$}

The effect of SR, BR, and their interaction on BW and BCS is presented in Table 7. Although the LSR group tended to be on average heavier $(P=0.08 ; 497$ $\mathrm{kg}$ ) compared with both MSR and HSR $(485 \mathrm{~kg})$, there was no significant SR effect on BW at calving, nadir, first AI, or dry off. There was also no significant overall SR effect on BCS over the complete lactation, with the exception of BCS at dry off, which was greater $(P=0.04)$ for LSR (3.03) compared with MSR (2.99) and HSR (3.00). Genotype had a significant effect on $\mathrm{BW}$ as HF cows were consistently heavier $(504 \mathrm{~kg} ; P$ $<0.001)$ than JxHF $(474 \mathrm{~kg})$ throughout the experiment. The greatest differential in BW between HF and JxHF cows was observed at dry off $(39 \mathrm{~kg})$, whereas the differential was least at first AI $(30 \mathrm{~kg})$. Jersey $\times$ Holstein-Friesian cows had greater mean BCS $(2.96 ; P$ $<0.05)$, BCS at calving $(3.16 ; P=0.07)$, and BCS at first insemination $(2.90 ; P<0.01)$ compared with $\mathrm{HF}$ cows $(2.94,3.14$, and 2.86 , respectively).

\section{Milk Production and Energy Utilization per Hectare}

The effect of SR, BR, and their interaction on productivity per hectare is presented in Table 8. Grazing days per hectare were greatest $(P<0.001)$ for HSR $(863 \mathrm{~d})$, intermediate for MSR (756 d), and least for LSR (658 d). Stocking rate had a significant effect on all milk production per hectare variables analyzed. As SR increased, there was a linear increase in milk and MS yield per hectare. Milk and MS yield was greatest $(P<0.001)$ for HSR $(15,942$ and $1,354 \mathrm{~kg}$, respectively), intermediate for MSR (14,191 and $1,220 \mathrm{~kg}$, respectively), and least for LSR (13,186 and 1,139 kg, respectively) with similar trends evident for fat, protein, and lactose yield per hectare. At higher SR (MSR and HSR), MS yield $/ \mathrm{kg}$ of BW per hectare was reduced (0.85 and $0.82 \mathrm{~kg}$ of $\mathrm{MS} / \mathrm{kg}$ of BW, respectively) compared with LSR (0.93 kg of MS/kg of BW per ha). Holstein-Friesian cows achieved fewer grazing days per hectare $(P=0.004 ;-37 \mathrm{~d})$, produced more milk $(P=$ $0.04 ;+561 \mathrm{~kg} / \mathrm{ha})$ but less SCM $(P=0.05 ;-571 \mathrm{~kg} /$ ha) and MS $(P=0.01 ;-57 \mathrm{~kg} / \mathrm{ha})$ compared with JxHF cows. In addition, JxHF cows produced more $(P$ $<0.001)$ MS yield per $\mathrm{kg}$ of BW per hectare $(0.90 \mathrm{~kg})$ compared with HF cows $(0.84 \mathrm{~kg})$. The greater milk production per hectare achieved at higher SR was also closely related to the number of grazing days per hectare $\left(\mathrm{r}^{2}=0.93\right)$ achieved in addition to increased grazed pasture utilization $\left(\mathrm{r}^{2}=0.65\right.$; Figure 1$)$. Each additional grazing day per hectare corresponds to increased MS production of $1.7 \mathrm{~kg}$ of MS per hectare and pasture utilization of $11 \mathrm{~kg}$ of DM per ha.

The effect of SR and BR on energy requirements for both maintenance and milk production, expressed in UFL, are presented in Table 9. As SR increased, a linear increase was observed in energy requirements per hectare. Maintenance and milk requirements per hectare were least in LSR (3,110 and 5,447, respectively), intermediate in MSR (3,669 and 6,494, respectively), and greatest in HSR (4,086 and 7,009, respectively). Similarly, pasture, silage, and concentrate utilization per hectare increased as SR increased, least in LSR (9,524, 274, and 1,151 UFL, respectively), intermediate in $\operatorname{MSR}(10,373,281$, and 1,308 UFL, respectively), and greatest in $\operatorname{HSR}(10,923,150$, and 1,446 UFL, respectively). Milk solids per hectare relative to total feed utilization (UFL/ha) was similar for LSR $(104 \mathrm{~g})$ and MSR (102 g), and greatest for HSR (108 g). Addition-

Table 5. Effect of stocking rate $^{1}$ on the chemical composition of pasture during the experiment

\begin{tabular}{lccccc}
\hline Item & Low & Medium & High & SEM & Significance \\
\hline CP (g/kg of DM) & 216 & 219 & 221 & 4.4 & 0.731 \\
OM digestibility (\%) & 78 & 79 & 79 & 0.4 & 0.251 \\
NDF (g/kg of DM) & 442 & 437 & 439 & 4.7 & 0.708 \\
ADF (g/kg of DM) & 256 & 258 & 257 & 2.6 & 0.927 \\
Ash (g/kg of DM) & 111 & 114 & 116 & 2.5 & 0.432 \\
UFL $^{2}$ & 0.96 & 0.98 & 0.97 & 0.009 & 0.576 \\
\hline
\end{tabular}

${ }^{1}$ Stocking rate: low $=1,200 \mathrm{~kg}$ of $\mathrm{BW} / \mathrm{ha}$; medium $=1,400 \mathrm{~kg}$ of $\mathrm{BW} / \mathrm{ha}$; high $=1,600 \mathrm{~kg}$ of $\mathrm{BW} / \mathrm{ha}$.

${ }^{2} \mathrm{UFL}=$ unité fourragère lait (the net energy content of $1 \mathrm{~kg}$ of standard barley; that is, 1,700 kcal; Faverdin et al., 2011). 


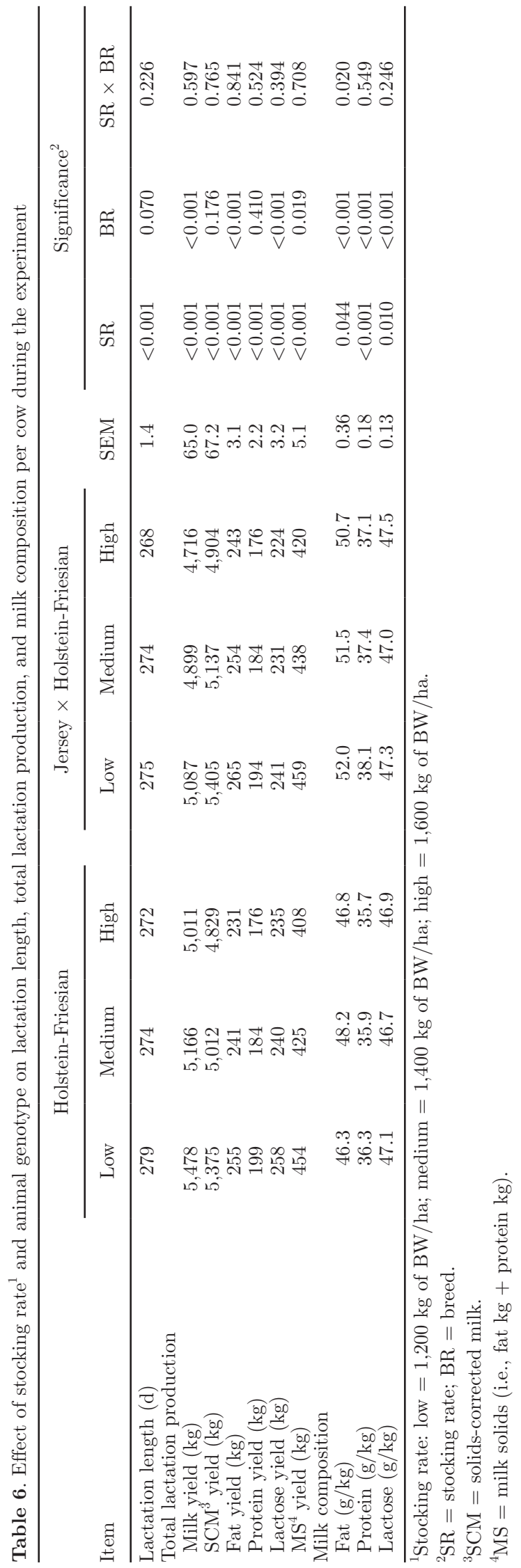

Journal of Dairy Science Vol. 101 No. 3, 2018

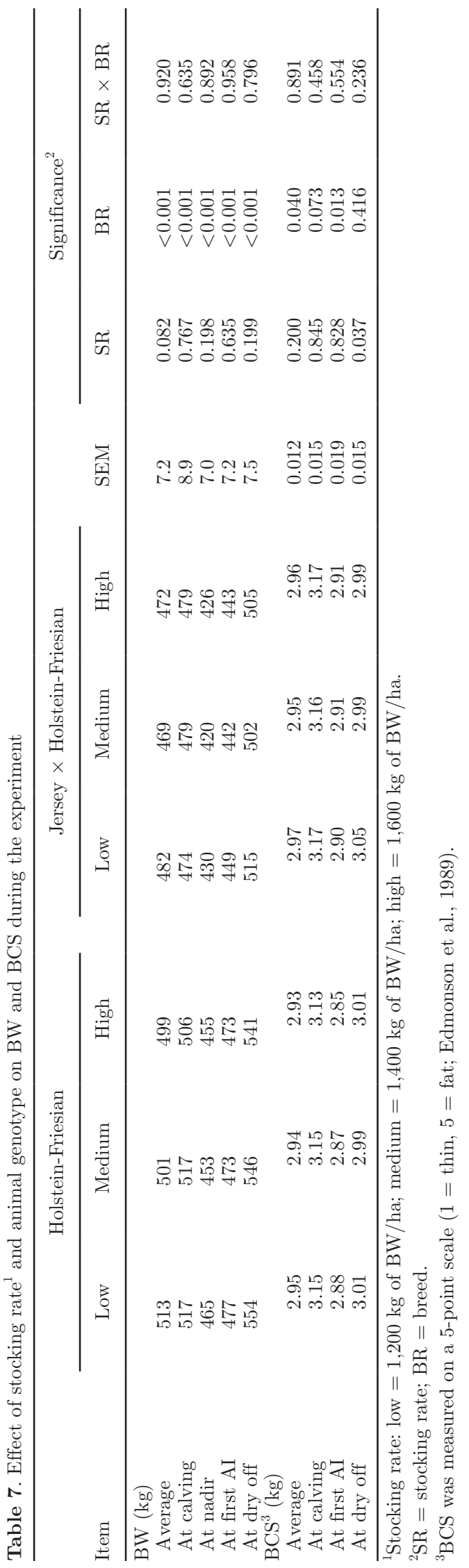




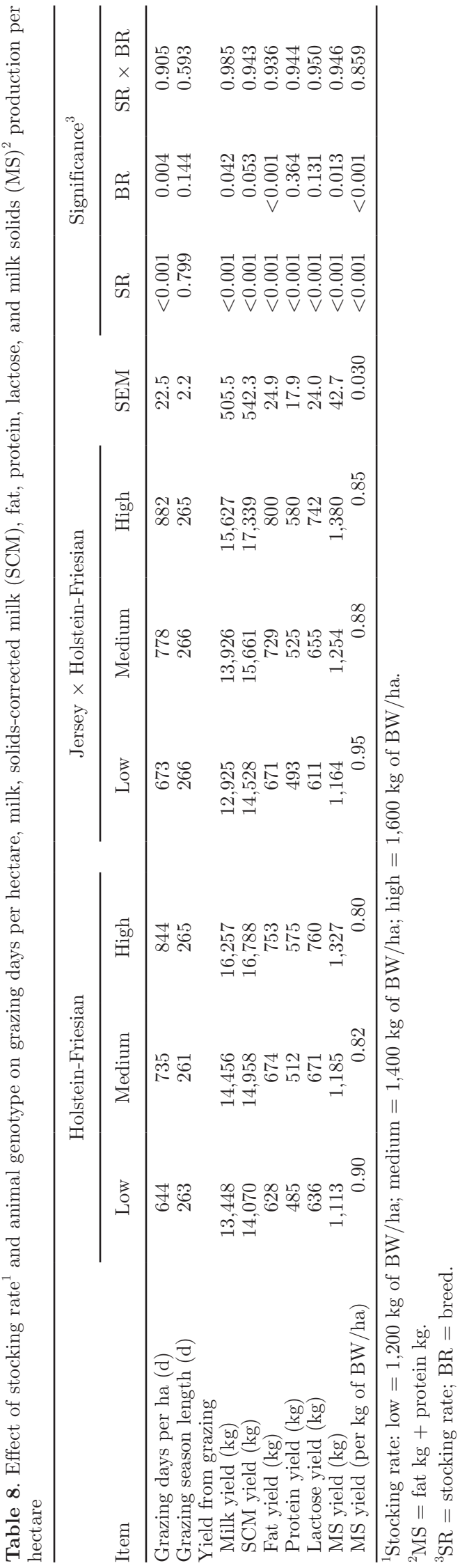

ally, JxHF cows produced more MS per hectare relative to total feed intake $(107 \mathrm{~g})$ compared with their HF counterparts (102 g).

\section{DISCUSSION}

Within intensive grazing systems, productivity is dependent on achieving a balance between the competing objectives of high DM allowance and intake to maximize milk production per cow, and increased grazing intensity to maximize pasture utilization and milk production per hectare (Coffey at al., 2017). In such contexts, the combination of cows capable of high pasture intake with SR capable of maximum pasture utilization efficiency is critical to overall systemic performance. This SR experiment was uniquely defined based on BW per hectare to evaluate the response to SR change using 2 different genotypes over a 4 -yr period within a consistent whole-farm systems framework design. The range of SR investigated within the present experiment (1,200 to $1,600 \mathrm{~kg}$ of $\mathrm{BW} / \mathrm{ha}$ and 75 to 95 $\mathrm{kg}$ of $\mathrm{BW} / \mathrm{t}$ of $\mathrm{DM}$ available) are within the normal biological ranges reported in the modern literature (Macdonald et al., 2008a; McCarthy et al., 2011). The approach taken in the experiment to describe both SR and cow performance at the paddock level facilitates the development of a robust cow response function within the SR literature while also investigating the interaction of SR and BR.

\section{Pasture Accumulation, Grazing Characteristics, and Dietary Details}

Despite summer rainfall deficits in both 2013 and 2014, average pasture accumulation over the $4 \mathrm{yr}$ of the present experiment $(15,550 \mathrm{~kg}$ of $\mathrm{DM} / \mathrm{ha})$ was similar to previous studies at the same research site (Coleman et al., 2010; McCarthy et al., 2016). Similar to previous studies, increasing SR and grazing intensity within the higher SR treatment in the present experiment had a positive effect on pasture accumulation and utilization. Although net pasture accumulation increased by an average of $604 \mathrm{~kg}$ of DM/ha (+4\% or $150 \mathrm{~kg}$ of DM/100 $\mathrm{kg}$ of additional BW) between LSR and HSR during the $4 \mathrm{yr}$, the overall pasture response to increasing SR is below that reported previously by McCarthy et al. $(2016 ; 291 \mathrm{~kg} / 100 \mathrm{~kg}$ of BW) and is reflective of the below average summer rainfall and growth during 2013 and 2014. As SR increased, the proportion of pasture harvested in the form of grazed pasture increased, whereas the proportion of silage decreased. In the HSR treatment, grazed pasture and silage accounted for 77 and $23 \%$ of net pasture accumulation, respectively, 
(a)

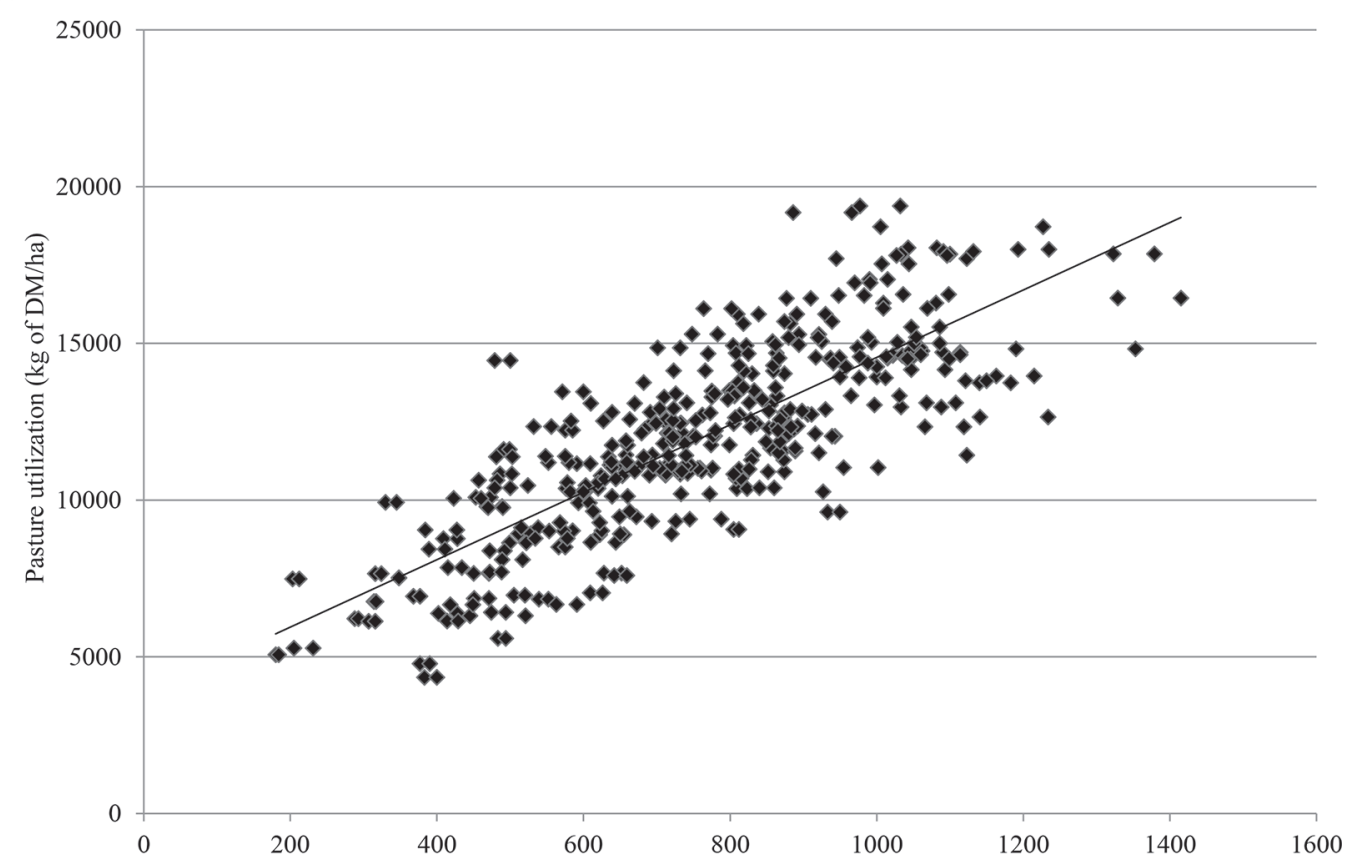

(b)

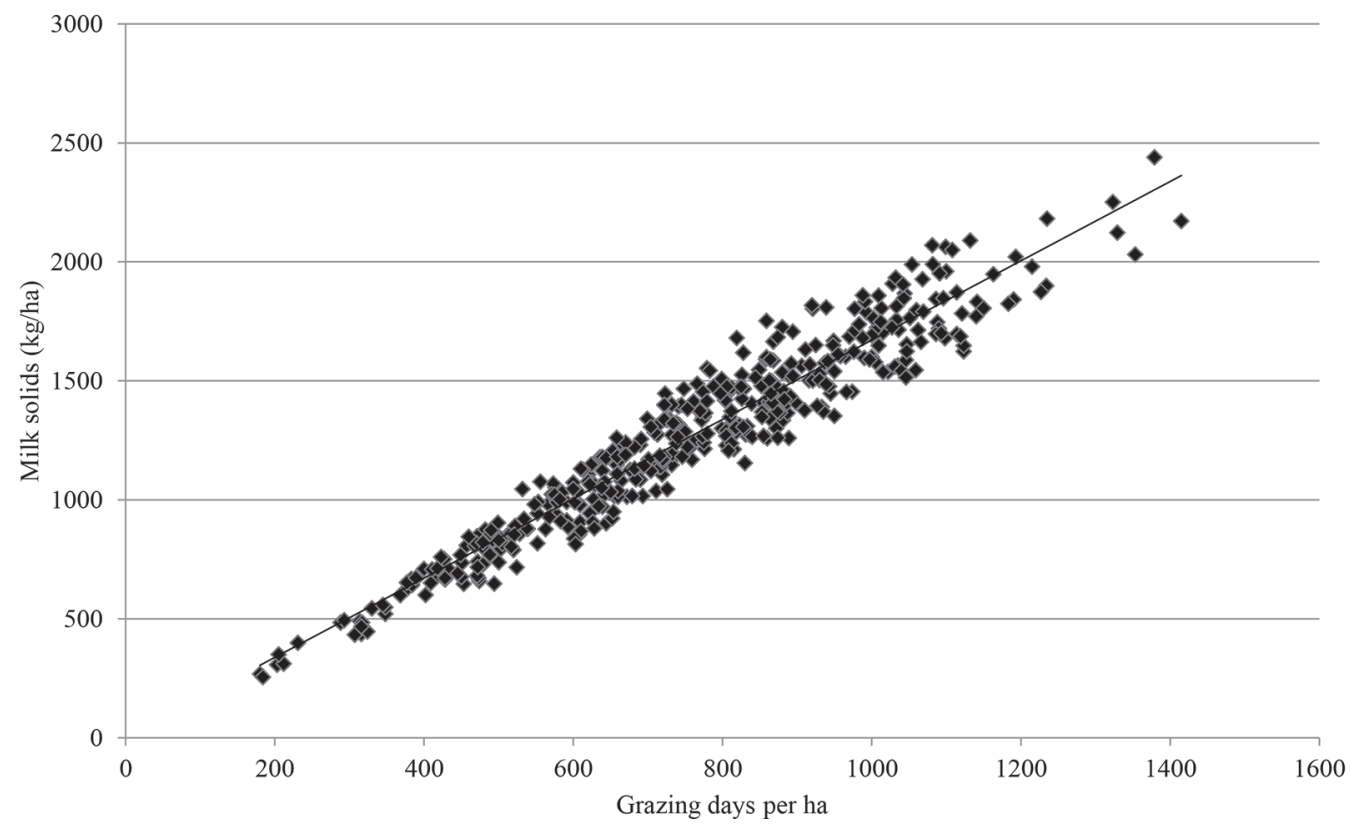

Figure 1. The relationship between grazing days per hectare and (a) pasture utilization (kg of DM/ha) and (b) milk solids (kg/ha).

compared with 70 and $30 \%$, respectively, of net accumulation in the LSR treatment. Sward nutritive quality was high during the experiment, and although the lack of difference between SR treatments is contrary to previous findings (Baudracco et al., 2010; McCarthy et al., 2016), for whole lactation farmlet studies with ryegrass pastures, consistent lower NDF (Macdonald et al., 2008a), higher CP content (Valentine et al., 2009), and higher pasture digestibility (McCarthy et al., 2016) were reported at higher SR. The comparatively high level of silage conservation in LSR and MSR treatments coupled with dry summers may have negated the 
typical adverse effects of poorer grazing management of LSR on sward nutritive quality within the current experiment.

Increasing SR is linked to a reduction in DPA (Baudracco et al., 2010; McCarthy et al., 2014). In the present experiment, DPA was 79 and $74 \%$ of that allocated to LSR for the MSR and HSR treatments, respectively. To arrest the decline in DPA at higher SR, cows grazed more intensively to a lower postGSH. Similar to both Macdonald et al. (2008a) and McCarthy et al. (2016), these factors contributed to a linear increase in pasture utilization as SR increased. Increasing SR resulted in a greater number of grazing days per hectare being achieved and a strong association was observed between grazing days per hectare increases in both grazed pasture utilization and MS output per hectare during the study period. Unlike previous BR comparison experiments consisting of similar numbers of cows per hectare and, consequently, individual feed allowances were provided (Prendiville et al., 2010; Vance et al., 2012), the uniquely equitable BW per hectare design employed within the present experiment resulted in higher individual DPA and pasture disappearance for larger HF cows $(+3.7$ and $+3.4 \%$, respectively), whereas overall paddock pasture utilization remained consistent across BR. Although the experiment was designed to achieve equal feed supplementation levels (kg concentrate plus silage per ha) in each SR and BR combination, this was not achieved due to restricted mid-season pasture growth as a result of reduced rainfall in both 2013 and 2014. Consequently, similar to previous experiments (Macdonald et al., 2008a; Baudracco et al., 2010), total lactation combined supplementation per hectare (silage and concentrate) was greater at higher $\mathrm{SR}(+150 \mathrm{~kg}$ of DM per hectare in MSR and HSR compared with LSR).

\section{Milk Production per Cow}

The propensity of HF cows to produce higher volumes of milk but fewer MS than JxHF has been documented previously in both research (Horan et al., 2005; Prendiville et al., 2011; Buckley et al., 2014) and commercial (Coffey et al., 2016) settings. The reduction in milk and MS yield between the base SR (LSR) and MSR (2.4 and $2.6 \% / 100 \mathrm{~kg}$ of additional BW, respectively) and HSR (2.0 and $2.3 \% / 100 \mathrm{~kg}$ of additional BW, respectively) treatments is consistent with the 2.0 and $2.3 \% / 100 \mathrm{~kg}$ of BW reported previously (Macdonald et al., 2008a; McCarthy et al., 2013). In a meta-analysis of the SR literature, McCarthy et al. (2011) reported a linear decline in milk and MS yield (3.1 and 2.7\%/100 $\mathrm{kg}$ of additional BW) as SR increased but also observed that the decline in milk production/cow at higher SR was affected by BW. In New Zealand grazing systems, Ahlborn and Bryant (1992) reported higher milk production from HF than Jersey cows, but also noted that Jersey cows produced additional milk per hectare as SR increased, and concluded that Jersey cows appear to have a greater tolerance to higher SR due to their lower BW. Although not deemed to be significant in the present experiment, MS yield per cow was reduced by $46 \mathrm{~kg}(10 \%)$ among HF cows as SR increased from LSR to HSR compared with a reduction of $39 \mathrm{~kg}(8 \%)$ for JxHF cows. This corroborates Ahlborn and Bryant (1992) and Bryant et al. (2007), where JxHF are better adapted to the lower feed allowances within higher SR grazing systems.

\section{$B W$ and BCS}

Changes in BW and BCS throughout lactation were minimal in all $6 \mathrm{SR}$ and $\mathrm{BR}$ treatment combinations.

Table 9. Effect of stocking rate $^{1}$ and animal genotype on energy requirements and energy utilization during lactation during the experiment

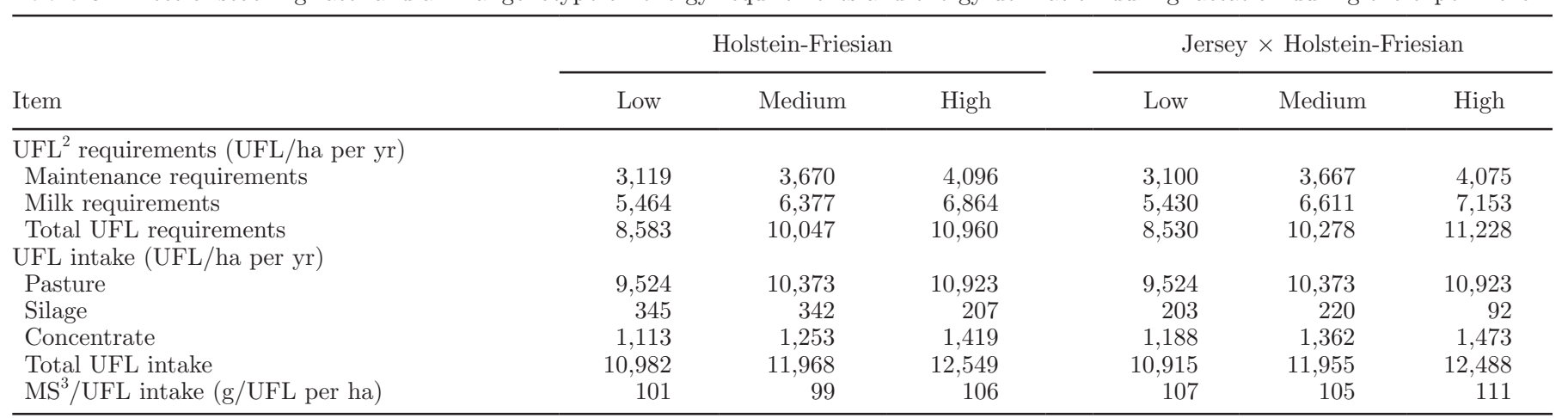

${ }^{1}$ Stocking rate: low $=1,200 \mathrm{~kg}$ of $\mathrm{BW} /$ ha; medium $=1,400 \mathrm{~kg}$ of $\mathrm{BW} / \mathrm{ha}$; high $=1,600 \mathrm{~kg}$ of $\mathrm{BW} / \mathrm{ha}$.

${ }^{2} \mathrm{UFL}=$ unité fourragère lait (the energy content of the $1 \mathrm{~kg}$ of standard barley; that is, 1,700 kcal; Faverdin et al., 2011).

${ }^{3} \mathrm{MS}=$ milk solids (i.e., fat $\mathrm{kg}+$ protein $\mathrm{kg}$ ). 
Increasing SR is commonly associated with a linear decline in BW (Dillon et al., 1995; McCarthy et al., 2013), yet this was not observed in the present experiment. Previous studies have also observed greater differentials in both BW and BCS between BR groups. Prendiville et al. (2009) and Vance et al. (2013) observed that HF were heavier than JxHF by 50 and $44 \mathrm{~kg}$, respectively, whereas JxHF had superior BCS $(+0.24$ and +0.17 BCS units, respectively) compared with HF contemporaries. Unlike these previous studies of similar contemporary groups, the mean BW of HF cows was only 6\% (30 $\mathrm{kg}$ ) greater than JxHF cows in the present experiment, whereas the BCS superiority of JxHF cows was modest (+0.02 BCS units). As SR increased from LSR to MSR, there was a $1.2 \%$ reduction in average BW per $100 \mathrm{~kg}$ of additional $\mathrm{BW}$, with no further reduction between MSR and HSR. The lack of effect of SR on BW and $\mathrm{BCS}$ is also indicative of the capability of both BR to graze more intensively to achieve adequate feed intake within high SR grazing systems. Furthermore, supplementation was provided at higher SR during periods of low pasture growth, thereby preventing greater losses of BW and BCS during periods of feed deficit. The lack of both BW and BCS responses to increasing SR in the present experiment is consistent with the improved DMI capability and increased BCS of high genetic merit (EBI) dairy cows reported previously within intensified grazing systems (Coleman et al., 2010; Moore et al., 2014).

\section{Milk Production and Energy Utilization per Hectare}

The significant positive effect of increasing SR on milk production per hectare has been consistently reported previously (McMeekan and Walshe, 1963; Macdonald et al., 2008a; McCarthy et al., 2013). Similar to Macdonald et al. (2008a) and McCarthy et al. (2016), the efficiency of feed utilization increased at higher SR in the present experiment $(+8.9$ and $14.7 \%$ for MSR and HSR, respectively). Greater feed utilization resulted in significantly greater milk productivity per hectare, corresponding to an additional $154 \mathrm{~kg}(+13.8 \%)$ and 268 $\mathrm{kg}(+24.0 \%)$ in MS per ha in MSR and HSR, respectively. In a meta-analysis of the literature, increasing SR by $100 \mathrm{~kg}$ of BW per ha resulted in a $2.0 \%$ increase in milk and $2.3 \%$ increase in MS production per hectare coupled with a $28 \%$ increase in the number of grazing days per hectare (McCarthy et al., 2011). As SR increased by each additional $100 \mathrm{~kg}$ of BW per ha from LSR to MSR and HSR in the present experiment, milk yield per hectare increased by 3.7 and $5.2 \%$, respectively, for HF cows and 3.4 and $5.2 \%$, respectively, for JxHF cows. The increase in grazing days per hectare at higher SR in the present experiment arises as a conse- quence of increased grazing efficiency, evident from an increase in pasture utilization, a lower postGSH, and a reduction in the proportion of total area conserved as silage. As SR increased from LSR to HSR, MS production per kilogram of BW per hectare decreased by $12 \%$, reflecting the increased maintenance requirements and consequently, reduced energy availability for milk production in higher SR grazing systems (Coffey et al., 2017). Accounting for energy requirements per hectare (maintenance and milk production) and energy intake from feed supplies (pasture, silage, and concentrate), MS production was similar for LSR and MSR, and 5\% greater for HSR.

Having equalized genotype in terms of BW per hectare in the present unique experimental design, SR (cows/ha) was $4.5 \%$ higher for JxHF. This resulted in an additional $5 \%$ increase in grazing days per hectare, and in additional milk and MS per hectare of 3.8 and $4.7 \%$, respectively, at similar feed input levels. Furthermore, JxHF were $7 \%$ more efficient at producing MS per kilogram of BW compared with HF contemporaries, which concurs with previous studies. When intake is expressed per unit of BW, Coffey et al. (2017) observed that JxHF cows had higher feed conversion efficiency, requiring less energy intake to produce $1 \mathrm{~kg}$ of MS. Production of MS relative to total feed intake was also consistently 5 to $6 \%$ higher for JxHF cows compared with HF cows across all SR treatments. The similarity in DMI and milk production between HF and smaller JxHF cows in previous studies has been attributed to several factors including differences in cow BW and grazing behavior (Prendiville et al., 2010; Vance et al., 2012), gastrointestinal tract weight (Beecher et al., 2014), DMI capacity (Goddard and Grainger, 2004), and NDF digestibility (Aikman et al., 2008). At an overall systems level and irrespective of the SR chosen, the present experiment quantifies the consistent superiority of JxHF cows to intensive grazing environments for the first time, resulting in $4.8 \%$ more MS per hectare and 5\% more MS per UFL of intake at grazing compared with their HF counterparts.

\section{CONCLUSIONS}

The present SR experiment was uniquely designed based on a BW per hectare framework to evaluate the response to SR changes, using differing animal genotypes over a 4 -yr period. The greater productivity per hectare demonstrated at higher SR is a consequence of increasing BW per hectare, increased grazing intensity, additional grazing days per hectare, and a greater level of grazed pasture utilization. At similar BW per hectare, JxHF cows produced significantly more fat plus protein per hectare during the grazing season at 
each SR. Although opportunity to improve efficiency is limited within intensive ruminant production systems, this experiment also demonstrates the superior capability of JxHF cows to maintain production efficiency per hectare and deliver increased MS production within intensive grazing systems with low supplementation levels.

\section{ACKNOWLEDGMENTS}

The authors thank the staff of Curtin's Research Farm (Animal \& Grassland Research and Innovation Centre, Teagasc Moorepark, Ireland) for their co-operation, care, and management of the experimental cows. The authors acknowledge the financial support of the Dairy Research Levy.

\section{REFERENCES}

Ahlborn, G., and A. M. Bryant. 1992. Production, economic performance and optimum stocking rate of Holstein-Friesian and Jersey cows. Proc. N.Z. Soc. Anim. Prod. 52:7-9.

Aikman, P. C., C. K. Reynolds, and D. E. Beever. 2008. Diet digestibility, rate of passage, and eating and rumination behavior of Jersey and Holstein cows. J. Dairy Sci. 91:1103-1114.

Baudracco, J., N. Lopez-Villalobos, C. W. Holmes, and K. A. Macdonald. 2010. Effects of stocking rate, supplementation, genotype and their interactions on grazing dairy systems: A review. N. Z. J. Agric. Res. 53:109-133.

Beecher, M., F. Buckley, S. M. Waters, T. M. Boland, D. EnriquezHidalgo, M. H. Deighton, M. O'Donovan, and E. Lewis. 2014. Gastrointestinal tract size, total-tract digestibility, and rumen microflora in different dairy cow genotypes. J. Dairy Sci. 97:3906-3917.

Berry, D. P. 2015. Breeding the dairy cow of the future: What do we need? Anim. Prod. (Purwokerto) 55:823-837.

Bryant, J. R., N. López-Villalobos, J. E. Pryce, C. W. Holmes, D. L. Johnson, and D. J. Garrick. 2007. Short Communication: Effect of environment on the expression of breed and heterosis effects for production traits. J. Dairy Sci. 90:1548-1553.

Buckley, F., N. Lopez-Villalobos, and B. J. Heins. 2014. Crossbreeding: Implications for dairy cow fertility and survival. Animal 8:122-133.

Coffey, E. L., L. Delaby, S. Fitzgerald, N. Galvin, K. M. Pierce, and B. Horan. 2017. Effect of stocking rate and animal genotype on dry matter intake, milk production, body weight, and body condition score in spring-calving, grass-fed dairy cows. J. Dairy Sci. 100:7556-7568.

Coffey, E. L., B. Horan, R. D. Evans, and D. P. Berry. 2016. Milk production and fertility performance of Holstein, Friesian, and Jersey purebred cows and their respective crosses in seasonal-calving commercial farms. J. Dairy Sci. 99:5681-5689.

Coleman, J., D. P. Berry, K. M. Pierce, A. Brennan, and B. Horan. 2010. Dry matter intake and feed efficiency profiles of 3 genotypes of Holstein-Friesian within pasture-based systems of milk production. J. Dairy Sci. 93:4318-4331.

Delaby, L., and J. L. Peyraud. 1998. Effect of a simultaneous reduction in nitrogen fertilization and stocking rate on the performance of dairy cows and pasture utilization. Anim. Zootech. 47:17-39.

Delgado, C. L. 2003. Rising consumption of meat and milk in developing countries has created a new food revolution. J. Nutr. 133:3907S-3910S.

Department of Agriculture, Food and the Marine. 2015. AIM Bovine Statistics Report 2015. Dublin, Ireland.
Dillon, P., S. Crosse, G. Stakelum, and F. Flynn. 1995. The effect of calving date and stocking rate on the performance of springcalving dairy cows. Grass Forage Sci. 50:286-299.

Dong, L. F., T. Yan, C. P. Ferris, and D. A. McDowell. 2015. Comparison of maintenance energy requirement and energetic efficiency between lactating Holstein-Friesian and other groups of dairy cows. J. Dairy Sci. 98:1136-1144.

Edmonson, A. J., I. J. Lean, L. D. Weaver, T. Farver, and G. Webster. 1989. A body condition scoring chart for Holstein dairy cows. J. Dairy Sci. 72:68-78.

Faverdin, P., C. Baratte, R. Delagarde, and J. L. Peyraud. 2011. GrazeIn: A model of herbage intake and milk production for grazing dairy cows. 1. Prediction of intake capacity, voluntary intake and milk production during lactation. Grass Forage Sci. 66:29-44.

Goddard, M. E., and C. Grainger. 2004. A review of the effects of dairy breed on feed conversion efficiency - an opportunity lost? Pages 77-80 in Proc. 25th Biennial Conf Aust. Soc. Anim. Prod. University of Melbourne, Victoria, Australia. CSIRO, Victoria, Australia.

Hoden, A., J. L. Peyraud, A. Muller, L. Delaby, P. Faverdin, J. R. Peccatte, and M. Fargetton. 1991. Simplified rotational grazing management of dairy cows: Effects of rates of stocking and concentrate. J. Agric. Sci. 116:417-428.

Holmes, C. W., G. F. Wilson, D. D. S. Mackenzie, D. S. Flux, I. M. Brookes, and A. W. F. Davey. 2002. Feeding the herd. Pages 33-89 in Milk Production from Pasture. Butterworths, Wellington, New Zealand.

Horan, B., P. Dillon, P. Faverdin, L. Delaby, F. Buckley, and M. Rath. 2005. The interaction of strain of Holstein-Friesian cows and pasture-based feed systems on milk yield, body weight, and body condition score. J. Dairy Sci. 88:1231-1243.

ICBF. 2014. Understanding the Economic Breeding Index (EBI) https://www.teagasc.ie/media/website/animals/dairy/ Understanding_EBI_PTA_BV_Spring_2014.pdf.

ICBF. 2015. Irish Cattle Breeding Federation. Accessed Dec. 10, 2015. http://www.icbf.com.

Kennedy, E., M. McEvoy, J. P. Murphy, and M. O'Donovan. 2009. Effect of restricted access time to pasture on dairy cow milk production, grazing behavior, and dry matter intake. J. Dairy Sci. 92:168-176.

Macdonald, K. A., J. W. Penno, J. A. S. Lancaster, and J. R. Roche. 2008a. Effect of stocking rate on pasture production, milk production, and reproduction of dairy cows in pasture-based systems. J. Dairy Sci. 91:2151-2163.

Macdonald, K. A., G. A. Verkerk, B. S. Thorrold, J. E. Pryce, J. W. Penno, L. R. McNaughton, L. J. Burton, J. A. S. Lancaster, J. H. Williamson, and C. W. Holmes. 2008b. A comparison of three strains of Holstein-Friesian grazed on pasture and managed under different feed allowances. J. Dairy Sci. 91:1693-1707.

Mackle, T. R., C. R. Parr, G. K. Stakelum, A. M. Bryant, and K. L. MacMillan. 1996. Feed conversion efficiency, daily pasture intake, and milk production of primiparous Friesian and Jersey cows calved at two different liveweights. N. Z. J. Agric. Res. 39:357-370.

McCarthy, B., L. Delaby, K. M. Pierce, A. Brennan, and B. Horan. 2013. The effect of stocking rate and calving date on milk production of Holstein-Friesian dairy cows. Livest. Sci. 153:123-134.

McCarthy, B., L. Delaby, K. M. Pierce, F. Journot, and B. Horan. 2011. Meta-analysis of the impact of stocking rate on the productivity of pasture-based milk production systems. Animal 5:784-794.

McCarthy, B., L. Delaby, K. M. Pierce, J. McCarthy, C. Fleming, A. Brennan, and B. Horan. 2016. The multi-year cumulative effects of alternative stocking rate and grazing management practices on pasture productivity and utilization efficiency. J. Dairy Sci. 99:3784-3797.

McCarthy, J., B. McCarthy, B. Horan, K. M. Pierce, N. Galvin, A. Brennan, and L. Delaby. 2014. Effect of stocking rate and calving date on dry matter intake, milk production, body weight, and body condition score in spring-calving, grass-fed dairy cows. J. Dairy Sci. 97:1693-1706. 
McMeekan, C. P., and M. J. Walshe. 1963. The inter-relationships of grazing method and stocking rate in the efficiency of pasture utilization by dairy cattle. J. Agric. Sci. 61:147-166.

Moore, S. G., T. Fair, P. Lonergan, and S. T. Butler. 2014. Genetic merit for fertility traits in Holstein cows: IV. Transition period, uterine health, and resumption of cyclicity. J. Dairy Sci. 97:27402752.

Morgan, D. J., G. Stakelum, and J. O'Dwyer. 1989. Modified neutral detergent cellulose digestibility procedure for use with the 'Fibertec' system. Isr. J. Agric. Res. 28:91-92.

Prendiville, R., E. Lewis, K. M. Pierce, and F. Buckley. 2010. Comparative grazing behavior of lactating Holstein-Friesian, Jersey, and Jersey $\times$ Holstein-Friesian dairy cows and its association with intake capacity and production efficiency. J. Dairy Sci. 93:764-774.

Prendiville, R., K. M. Pierce, and F. Buckley. 2009. An evaluation of production efficiencies among lactating Holstein-Friesian, Jersey, and Jersey $\times$ Holstein-Friesian cows at pasture. J. Dairy Sci 92:6176-6185.

Prendiville, R., L. Shalloo, K. Pierce, and F. Buckley. 2011. Comparative performance and economic appraisal of Holstein-Friesian, Jersey and Jersey x Holstein-Friesian cows under seasonal pasturebased management. Ir. J. Agric. Food Res. 50:123-140.

Pretty, J. N. 1997. The sustainable intensification of agriculture. Natural resources forum. Vol. 21. No. 4. pp. 247-256. United Nations. Published by Elsevier Science Ltd.

Robinson, T. P., G. R. W. Wint, G. Conchedda, T. Van Boeckel, M. Mcleod, B. Bett, D. Grace, and M. Gilbert. 2015. The global livestock sector: Trends, drivers, and implications for society, health and the environment. Page 6 in Science with Impact Annual Conference 2015-BSAS/AVTRW/WPSA. 4-15 April 2015. University of Chester, Chester, United Kingdom.

SAS Institute Inc. 2010. User's Guide: Statistics. Version 9.3. SAS Institute Inc., Cary, NC.

Shalloo, L., S. O'Donnell, and B. Horan. 2007. Profitability dairying in an increased EU milk quota scenario. Pages 20-44 in National Dairy Conference: Exploiting the Freedom to Milk. Teagasc, Carlow, Ireland.

Tyrrell, H. F., and J. T. Reid. 1965. Prediction of the energy value of cow's milk. J. Dairy Sci. 48:1215-1223.

Valentine, S., P. Lewis, R. T. Cowan, and J. Defaveri. 2009. The effects of high stocking rates on milk production from dryland and irrigated Mediterranean pastures. Anim. Prod. Sci. 49:100-111.

Van Soest, P. J. 1963. Use of detergents in the analysis of fibrous feeds. 2. A rapid method for the determination of fiber and lignin. J. Assoc. Off. Agric. Chem. 46:829-835.

Vance, E. R. C. P. Ferris, C. T. Elliott, H. M. Hartley, and D. J. Kilpatrick. 2013. Comparison of the performance of Holstein-Friesian and Jersey, and Holstein-Friesian crossbred dairy cows within three contrasting grassland-based systems of milk production. Livest. Sci. 151:66-79.

Vance, E. R., C. P. Ferris, C. T. Elliott, S. A. McGettrick, and D. J. Kilpatrick. 2012. Food intake, milk production, and tissue changes of Holstein-Friesian and Jersey $\times$ Holstein-Friesian dairy cows within a medium-input grazing system and a high-input total confinement system. J. Dairy Sci. 95:1527-1544. 